\title{
Evaluación de la bondad de ajuste de dos modelos empíricos aplicados a lactaciones de ovejas East Friesian
}

\author{
Evaluation of goodness of fit of two empirical models applied to East Friesian \\ sheep lactations
}

\author{
Mariana García Rendón Calzada ${ }^{a}$, Carlos Antonio López Díaz ${ }^{a}$, Antonio Ortiz Hernández ${ }^{a}$, \\ Augusto Lizarazo Chaparro ${ }^{a}$, Mohammed Benaouda ${ }^{b}$, Juan Carlos Angeles-Hernandez ${ }^{* *}$
}

\begin{abstract}
:
Sheep milk production is an important economic activity in some countries of Europe and Asia. However, in the last decades there has been an incipient development of this industry in some Latin American countries. The aim of the current work is to evaluate the goodness of fit of two empirical models to describe lactations curves of East Friesian sheep in a temperate region in Mexico. A total of 38 lactations, comprising 254 test-day records (TDR) of East Friesian sheep from a commercial dairy farm located in the Jilotepec, Estado de Mexico, Mexico, were analyzed to investigate the goodness of fit of two empirical lactation models (Wood and Wilmink models). The goodness of fit of empirical models was evaluated using the mean square of prediction error (MSPE), root-mean-square prediction error (RMSPE), Akaike information criterion (AIC) and Bayesian information criterion (BIC). According with the used criteria the Wood model depicts better fitting of analyzed lactation curves with lower values of MSPE (0.013 vs. 0.014), RMSPE (0.101 vs 0.104$)$, AIC (-5.67 vs. -5.03$)$ and BIC (-6.11 vs. -4.84$)$ in comparison with the Wilmink model.
\end{abstract}

\section{Keywords:}

Lactation curve, dairy sheep, mathematical modelling

\section{Resumen:}

La producción de leche de oveja es una actividad económica importante en algunos países de Europa y Asia. Sin embargo, en las últimas décadas ha habido un incipiente desarrollo de esta industria en algunos países de Latinoamérica. El objetivo del presente trabajo es evaluar la bondad de ajuste de dos modelos empíricos para describir las curvas de lactancia de las ovejas de East Friesian en una región templada de México. Se analizaron un total de 38 lactancias, las cuales comprenden un total de 254 registros de días de prueba (TDR) de ovejas East Friesian alojadas en una unidad de producción ovina lechera ubicada en Jilotepec, Estado de México, México, para investigar la bondad de ajuste de dos modelos empíricos (el modelo de Wood y el modelo de Wilmink). La bondad de ajuste de los modelos empíricos se evaluó utilizando el cuadrado medio del error de predicción (MSPE), el error de predicción de la raíz cuadrada media (RMSPE), el criterio de información de Akaike (AIC) y el criterio de información Bayesiana (BIC). De acuerdo con los criterios utilizado, el modelo de Wood muestra un mejor ajuste de las curvas de lactancia analizadas, mostrando valores más bajos de MSPE (0.013 vs 0.014), RMSPE (0.101 vs 0.104), AIC (-5.67 vs -5.03) y BIC (-6.11 vs. -4,84) en comparación con el modelo de Wilmink.

\section{Palabras Clave:}

Curva de lactación, oveja lechera, modelación matemática

\footnotetext{
aUniversidad Nacional Autónoma. de México. Mariana García Rendón Calzada, https://orcid.org/0000-0001-9437-1256, Email: mariana.garcia.rendon@gmail.com; Carlos Antonio López Díaz, https://orcid.org/0000-0003-4070-3926, Email: clopezd@unam.mx; Antonio Ortiz Hernández, https://orcid.org/0000-0001-7441-1265, Email: ortizh@unam.mx; Augusto Lizarazo Chaparro, https://orcid.org/0000-0001-9421-2087, Email: lizarazo@unam.mx.

b AgroSup Dijon, Francia. Mohammed Benaouda, https://orcid.org/0000-0002-0143-7007, Email: mohammed.ben-aouda@agrosupdijon.fr 'Universidad Autónoma del Estado de Hidalgo. Juan Carlos Ángeles Hernández, https://orcid.org/0000-0001-5303-1685, Email: juan_angeles@uaeh.edu.mx.
}

*Autor de Correspondencia: Email: juan angeles@uaeh.edu.mx 


\section{Introduction}

Sheep milk production is an important economic activity in some countries of Europe and Asia. Interestingly, in the last decades there has been an incipient development of this industry in some Latin American countries. In order to make this activity cost-effective the use of breeds specialized in milk production is important. Recently, breeds such as East Friesian, Lacaune and Awassi have been introduced in Mexico to achieve profitable milk yields. Nevertheless, there is scarce information about milk production levels and lactation curves characteristics of dairy ewes in this country, which limits the implementation of strategies to improve and evaluate their performance [1].

The lactation curve is a graphical representation of milk production over time. According to Pollot [2] studies of complete lactations are rare due to the common practice of weaning lambs at least 30-day post-partum. The records of milk production obtained after this suckling period matches with the declining phase of lactation, making impossible to estimate the rising phase and peak of lactation to describe the complete curve. In order to assess plausible lactation curves, it is required to record milk yield throughout the whole lactation [3].

Several mathematical models have been developed to describe lactation curves. Mathematical models to fit lactation curves can be classified according with the deep of approach to the biological process in empirical and mechanistic. The Wood function [4] is the most used empirical model to fit lactation curves because it allows to calculate the main characteristics of lactation curve as peak yield, time to peak yield and persistence with only three parameters $(a, b$ and $c)$. Wood parameters have also a partial biological interpretation. Several alternative models are based on the Wood model, such is the case of Wilmink model [5], with an additional parameter $k$ which is associated with the peak yield.

The aim of the current work is to evaluate the goodness of fit of two empirical models to fit lactations curves of East Friesian sheep in a temperate region in Mexico.

\section{Materials and methods}

\subsection{Database}

A total of 38 lactations comprising 254 test-day records (TDR) of East Friesian sheep from a commercial dairy farm located in Jilotepec, Estado de Mexico, Mexico, were analyzed to investigate the goodness of fit of two empirical lactation models. This region is at 2,440 meters above sea level and presents a mean temperature between 14 and $16^{\circ} \mathrm{C}$ and an average annual rainfall of $750 \mathrm{~mm}$ [6]. All ewes lambed between August and September of 2019 and lambs were allowed to suck the first 5 days post-partum. After weaning, ewes were feed with pasture, silage, wheat hydroponic green forage and concentrate with $16 \%$ of crude protein.

Ewes were mechanically milked twice daily, at 9:00 $\mathrm{h}$ and 15:30 h. Only lactations with the following information were considered for the analysis: ewe identity, lambing date, lambing number and type of lambing. Lactations averaged 7.2 TDR with minimum of five and maximum of 8 TDR, the first TDR was taken at day 21 post-lambing and lactation length ranged between 100- and 108-days postlambing.

\subsection{Mathematical models}

To analyze the lactation curves and their parameters, we used the two empirical mathematical models:

Wood model [4]:

$$
Y_{t}=a t^{b} e^{-c t}
$$

where $\mathrm{Y}$ is the milk production $(\mathrm{kg})$ at time $\mathrm{t}$, and $\mathrm{a}, \mathrm{b}$ and $c$ are the parameters describing the curve shape: $a$ is the production of milk at the beginning of the lactation $(\mathrm{kg})$, and $b$ and $c$ are the parameters of inclining and declining slopes of the lactation curve before and after the peak of production, respectively.

Wilmimk model [5]:

$$
Y=a+b e^{k t}+c t
$$


Where $a, b$, and $c$ are associated parameters with production level (a); milk production increase before peak (b); and decrease after peak (c) of lactation. The $\mathrm{k}$ parameter assumes a fixed value derived from a preliminary analysis and is associated with the time at peak yield [5].

\subsection{Evaluation of goodness of fit}

The goodness of fit of empirical models was evaluated using the mean square of prediction error (MSPE), calculated as:

$$
M S P E=\frac{\sum_{t=1}^{n} e_{t}^{2}}{n-p}
$$

where $e_{t}$ is the residual for the milk yield at day $t$ of the TDR, $n$ is the number of TDR in the lactation and $p$ is the number of parameters of the Wood and Wilmink models.

Also was calculated to each lactation the root-meansquare prediction error (RMSPE):

$$
R M S P E=\sqrt{M S P E}
$$

Where MSPE is the mean square of prediction error.

Finally, Akaike information criterion (AIC) and Bayesian Information criterion (BIC) were used as indicators to evaluate the goodness of fit of the two empirical models used.

The Wood and Wilmink parameters were estimated through the iterative nonlinear curve fitting procedure of regression analysis using the "nls" function of the "minpack" package [7] in the R software [8].

\section{Results}

Criterions of goodness of fit to evaluate the performance of Wood and Wilmink models applied to lactation curves of East Friesian sheep are showed in Table 1. According with the used criteria the Wood model depicts better fitting of analyzed lactation curves with lower values of MSPE (0.013 vs. 0.014$)$, RMSPE (0.101 vs 0.104$)$, AIC (-5.67 vs. -5.03$)$ and BIC (-6.11 vs. -4.84$)$ in comparison with the Wilmink model.
Table 1. Goodness of fit evaluation of Wood and Wilmink model fitted to East Friesian lactations.

\begin{tabular}{lllll}
\hline Model & MSPE & RMSPE & AIC & BIC \\
\hline Wood & 0.013 & 0.101 & -5.67 & -6.11 \\
Wilmink & 0.014 & 0.104 & -5.03 & -4.84
\end{tabular}

MSPE, mean square of prediction error; RMSPE, root-meansquare prediction error; AIC, Akaike information criterion; BIC; Bayesian Information criterion.

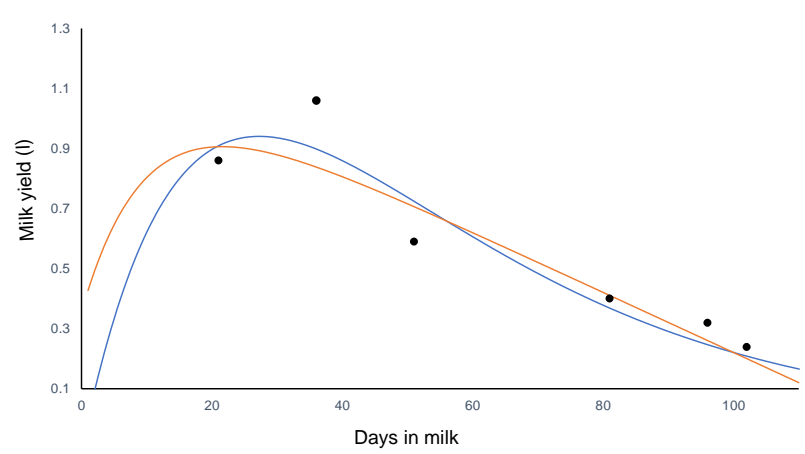

Figure 1. Lactation curves of East Friesian sheep fitted using the Wood $(-)$ and Wilmink model (-). Actual values $(\bullet)$.

Figure 1 illustrates the average lactation curves using the parameters of the Wood and Wilmink models and the actual values of milk yield. According with the lactations curves both models showed an adequate estimation of milk yield in the second part of lactation. The differences of fit were allocated in the first part of lactation, near to peak of lactation, where the Wilmink model depicts an under estimation of milk yields.

\section{Discussion}

According with our goodness of fit evaluation the Wood model showed a better performance to estimates milk yield production of East Friesian sheep in comparison with the Wilmink model. Although, both empirical models showed adequate values of MSPE, RMSPE, AIC and BIC.

Our findings are in line with the results of other studies who compared these models on dairy sheep lactations. For instance, Bilgin et al. [9] reported a better fit of Wood model with lactations of Awassi, 
Morkaraman and Tushin sheep, showing lower values of MSPE in comparison with Wilmink model.

On the other hand, some studies demonstrate better performance of the Wilmink model. AngelesHernandez [10] and Ruiz [11] reported better fit of lactation of dairy sheep using the Wilmink model with lower values of MSPE. In the same line, Olori et al. [12] compared this function with other empirical models (including Wood model) pointing out that Wilmink is the best model with three parameters to predict milk yield because it shows the smallest and least correlated residuals.

Some limitations have been reported to fit lactation curves using the Wood model. These limitations include the underestimation of milk production and total milk yield, overestimation of yields in the first part of the lactation curve and a high correlation between its parameters [2, 13]. Furthermore, another major criticism of Wood's model is that at time zero (calving/lambing time) milk production is also zero, which is biologically incorrect [14].

Mathematical models of lactation curves, like the ones proposed by Wood and Wilmink, allow to improve decision-making in relation to management and breeding [15], therefore a good fit is crucial. The results of the current work showed that Wood model have an adequate fit of lactation curves as well as it shows important advantages such as its simplicity and accuracy. However, their estimations and parameters must be carefully interpreted, mainly in the presence of atypical shapes of lactation curves [16].

\section{Conclusions}

Wood model is a useful empirical model to fit lactation curves in East Friesian sheep housed on commercial farms under temperate climate conditions in Mexico.

\section{Acknowledgments:}

Authors are grateful to Mexican Ministry of Education for funding this research Project under grant PRODEP UAEH-PTC-823. Mariana García Rendón Calzada was granted with a CONACyT fellowship for her Master studies. Also, the authors are grateful to
"Rancho el Paraiso" for their kind assistance regarding data collection of this study.

\section{Conflicts of Interest:}

The authors declare no conflict of interest.

\section{References}

[1] Ángeles-Hernández J. C., Pollott G., Albarrán-Portillo B., RamírezPérez A. H., Lizarazo-Chaparro A., Castelán O. O. A., González R. M. The application of a mechanistic model to analyze the factors that affect the lactation curve parameters of dairy sheep in Mexico. Small Ruminant Research. $2018 ; \quad 164:$ 58-63. https://doi.org/10.1016/j.smallrumres.2018.05.003

[2] Pollott G.E., Gootwine E. Appropriate mathematical models for describing the complete lactation of dairy sheep. Animal Science. 2000; 71: 197-207. DOI:10.1017/S1357729800055028

[3] Dag B., Keskin I., Mikailsoy F. Application of different models to the lactation curves of unimproved Awassi ewes in Turkey. South African Journal of Animal Science. 2005; 35, 4: 238-243. DOI: 10.4314/sajas.v35i4.3965

[4] Wood P. D. P. Algebraic model of the lactation curve in cattle. Nature. 1967; 216: 164-165.

[5] Wilmink J. B. M. Adjusted of test-day milk, fat and protein yield for age, season and stage of lactation. Livestock Production Science. 1987; 16: $335-348$.

[6] Ávila E. M. I. Efecto de la biocolina a diferentes dosis en ovinos productores de leche en pastoreo [Tesis de maestría, Universidad Nacional Autónoma de México]. TESIUNAM. 2020. http://132.248.9.195/ptd2019/diciembre/0799053/Index.html

[7] Elzhov T.V., Mullen K. M., Spiess A.N., Bolker B., 2016 Minpack.lm: $\mathrm{R}$ Interface to the Levenberg-Marquardt Nonlinear Least-Squares Algorithm Found in MINPACK, Plus Support for Bounds. R package version 1.2-1. https://CRAN.R-project.org/package=minpack.lm

[8] R Core Team, 2016. R: A Language and Environment for Statistical Computing.

[9] Bilgin O. C., Esenbuga N., Davis M. E. Comparison of models for describing the lactation curve of Awassi, Morkaraman and Tushin sheep. Archiv Tierzucht. 2010, 53, 4: 447-456.

[10] Ángeles-Hernández J. C., Abarrán-Portillo B., Gómez González A. V., Pescador Salas N., González-Ronquillo M. Comparison of the mathematical models applied to F1 dairy sheep lactations in organic farm and environmental factors affecting lactation curve parameter. Asian Australas. J. Anim. Sci. 2013; 26, 8: 1119-1126. doi: 10.5713/ajas.2013.13096

[11] Ruiz R., Oregui L. M., Herrero M. Comparison of models for describing the lactation curve of Latxa sheep and an analysis of factors affecting milk yield. Journal of Dairy Science. 2000; 83,11: 2709-2719. https://doi.org/10.3168/jds.S0022-0302(00)75165-4

[12] Olori V. E., Brotherstone S., Hill W. G., McGuirk B. J. Fit of standard models of the lactation curve to weekly records of milk production of cows in a single herd. Livestock Production Science. 1999, 58: 55-63. doi:10.1016/S0301-6226(98)00194-8. 
[13] Portolano, B., Spatafora, F., Bono, G., Margiotta, S. Todoro. M., Ortoleva, V. \& Leto, G. Application of the Wood model to lactation curves of Comissana sheep. Small Rumin. Res. 1996; 24, 7-13 https://doi.org/10.1016/0921-4488(95)00842-X

[14] Macciotta N. P. P., Dimauro C., Rassu S. P. G., Steri R., Pulina G. The mathematical description of lactation curves in dairy cattle. Ital J Anim Sci. 2011, 10: 51-213. doi:10.4081/ijas.2011.e51.

[15] Karangeli M. Abas Z. Koutroumanidis T., Malesios C., Giannakopoulos C., 2011. Comparison of models for describing the lactation curves of Chios sheep using daily records obtained from an automatic milking system. In: M. Salampasis, A. Matopoulos, editors. Proceedings of the International Conference on Communication Technologies for Sustainable Agri-production and Environment. 8-11 Sept 2011; Skiathos, Greece. p. 571-89

[16] Ángeles H. J. C., Castelán O. O., Albarrán P. B., Montaldo H. H., González R. M. Application of the Wood model to analyse lactation curves of organic dairy sheep farming. Animal Production Science. 2014; 54: 1609-1614. http://dx.doi.org/10.1071/AN14272 